\title{
The Law Under Stress after September 11
}

\author{
HAROLD HONGJU KOH*
}

Collectively, you law librarians gathered here must have been affected by the many legal fallouts from September 11: the Office of Homeland Security, the USA Patriot Act, the Use of Military Force Resolution; the thousands of casualties of all nationalities; the detainees; the military commissions; the prosecutions; the habeas cases. But even as you have studied and researched these individual issues, you have probably wondered whether something bigger is going on. Are these legal fallouts only symptoms of a much larger phenomenon: a post-World War II legal system placed under stress by September 11 ?

If that is what you suspect, you are surely right. In law school, you learned certain legal dichotomies: between war and peace, public and private, domestic and international, and civil and criminal. But since September 11, all of these traditional dichotomies have gotten muddied. We are now embroiled in a politically declared, but legally undeclared war, not against public entities or sovereign states, but a nonstate actor, a terrorist network and the countries that harbor terrorists (whatever "harbor" means). That war is being waged on both domestic and international fronts, and civil and criminal sanctions are being used interchangeably. As a result, predictably, when any particular issue surfaces, we don't know immediately which legal box to put it in. Take, for example, the legal status of al-Qaeda and Taliban detainees on Guantanamo. Are they prisoners of war - a term from the international laws of war? Or are they common criminals, a term of domestic criminal law? Or are they "unlawful combatants" - a category resurrected from World War II and expanded effectively to take them outside the scope of the law altogether?

- Gerard C. and Bernice Latrobe Smith Professor of International Law, Yale Law School. These remarks were first delivered to the MSL-J Reunion in April 2002. ๑Harold Hongju Koh 2003. 
On reflection, this blurring of lines is not surprising. To the contrary, this is what globalization looks like. In the age of globalization, traditional dichotomies have gone out the window. My Yale history colleague, John Lewis Gaddis, likes to say that the post-Cold War era began in November 1989, with the collapse of one structure, the Berlin Wall; and ended on September 11, 2001 with the collapse of another, the World Trade Center. Between these two collapses, we have passed almost literally out of the light and into the dark side of the age of globalization. When we look back, we will probably remember the period from 1989-2001 as the age of global optimism and the post-September 11 period as an age when global pessimism began to prevail.

This transition from global optimism to pessimism is best illustrated by looking at three areas of law: the use of force, the rise of the global justice system, and the relationship between civil liberties and national security at home.

Take the use of force. At the dawn of the post-Cold War era, the international law rules for using force seemed pretty clear: one state could lawfully breach another's territorial sovereignty only if one or more of three conditions obtained: response to aggression, self-defense, or a U.N. Security Council resolution. The Gulf War, which began in 1991, epitomized all three: the United States led a coalition authorized by U.N. Security Council resolution to respond to Saddam Hussein's aggression to come to the defense of Kuwait.

But two questions lingered. First, when may force be used in defense of human rights or humanitarian concerns without a Security Council resolution (the doctrine of "humanitarian intervention")? Second, when may force be used in "pre-emptive self-defense," to head off an attack that seems imminent, but has not yet occurred? For much of the decade after the Gulf War, the United States explored the contours of the humanitarian intervention doctrine: from Somalia, to Bosnia, to Kosovo, to East Timor to Sierra Leone. But September 11 - the most vicious of a series of brutal attacks on civilians suddenly posed a crisis at the crossroads of humanitarian intervention and preemptive self-defense. When and where, international lawyers asked, could the U.S. now justify using force collectively, without a Security Council resolution, to minimize human rights abuse against innocent civilians and to prevent future attacks on our citizens and territory? When the post-September 11 Security Council resolutions stopped short of explicitly authorizing military attacks on any particular country, the United States invoked a mixed 
humanitarian/self-defense rationale to strike back at Afghanistan. Having achieved impressive military success in the Afghanistan phase of the campaign, what rationale should the U.S. now use to justify the next stage?

At this moment, the Bush Administration seems increasingly attracted to arguments based on pre-emptive self-defense: putting troops in the Philippines, and even studying proposals for an "offensive deterrence" policy, which would allow the U.S. to use nuclear weapons against states who seem likely to use weapons of mass destruction. But pre-emptive self-defense arguments cannot clearly distinguish between permitted defensive measures and forbidden assaults: witness, for example, Israel's recent sweep into the West Bank, which could similarly be rationalized as pre-emptive self-defense against future terrorist attacks. Unlike the preemptive self-defense claim, which knows few limits, the humanitarian/human rights argument at least has the advantage that the United States cannot logically invoke human rights as its justification for force without simultaneously accepting human rights constraints as one measure of the rectitude of its actions. Significantly, when the U.S. finally went to war against Iraq in March 2003, it relied not on pre-emptive selfdefense arguments, but on claimed legal authority under prior Security Council resolutions. ${ }^{1}$

A second illustration is the rise of the global justice system. In retrospect, the early post-Cold War years revived and rejuvenated the Nuremberg concept of adjudication of international crimes. That rejuvenation found expression in the International Criminal Tribunals for the Former Yugoslavia and Rwanda, the Lockerbie trial, the move to create mixed international-domestic tribunals in Cambodia and Sierra Leone, the Pinochet prosecution in Spain and Chile, and the civil adjudication of international human rights violations in U.S. courts under the Alien Tort Claims Act. From the U.S. perspective, the symbolic high-water mark came on December 31, 2000, when President Clinton signed the International Criminal Court Treaty during his last days in office, a treaty that entered into force in April 2002.

But in the wake of September 11, every one of these hallmarks of the age of optimism about global justice seems under stress. With the trial of Slobodan Milosevic, the Yugoslav Tribunal faces its make-or-break case. The $R$ wanda Tribunal has been singularly unsuccessful, and the Lockerbie result

\footnotetext{
' For a critique of this legal rationale, see Harold Hongju Koh, "On American Exceptionalism," 55 Stanford Law Review 1479 (2002).
} 
disappointed Western governments. For a time, the U.N. pulled out of the Cambodia Tribunal, and the Sierra Leone Tribunal has yet to hear any case. Pinochet was never tried and a follow-on effort to try Chadian dictator Hissene Habre in Senegal stalled. Academic commentators and some judges have started to challenge the rise of human rights litigation in U.S. courts.

Three recent Administration decisions have now cut sharply against the development of a global justice system. First, in May 2002, the White House made a novel and troubling decision to "unsign" the ICC Treaty; second, the U.S. announced that it would cease funding the Yugoslav and Rwandan Tribunals by 2008 , but failed to specify clearly that this de-funding would be conditioned upon participating countries cooperating fully with those tribunals, thus potentially encouraging foot-dragging measures by defendants designed to wait out the tribunals. Third, the much-criticized U.S. proposal to try certain foreign terrorist suspects for war crimes before ad hoc military commissions has signaled a symbolic "unsigning" from international criminal adjudication. Each of these proposals ignores two realities: first, that the United States has promoted international criminal adjudication as being in our long-run national interest; and second, the fact that in many cases, supporting adjudication has spared us from far more costly military interventions. Without the Yugoslav Tribunal, for example, how could we have avoided sending troops to Belgrade to seize Milosevic?

My third example is the relationship between national security and civil liberties. As of 1989, following the traumas of Vietnam, Watergate, and the Iran-Contra Affair, three principles marked the equilibrium by which the United States had chosen to balance national security and civil liberties. The first is the idea that our government does not spy on us. We keep domestic law enforcement and foreign intelligence separate, and do not substitute the latter for the former, in order to guarantee the constitutional rights of the criminally accused. Second, we believe in equal justice for all, including aliens. Once admitted to our shores, lawfully admitted aliens enjoy roughly the same political and civil rights in the United States as citizens (except the right to vote), and foreign-born Americans are not relegated to underclass status with second-class rights. Third, even in wartime, we have accepted the role of the constitutional principle of checks and balances. While the executive branch must lead in national security affairs, all executive action in this area should be subject to meaningful legislative oversight and judicial review, on the theory that checks and balances require the President to make his case to - and 
persuade - elected legislators and independent judges who do not work for him.

During my time in government, I learned that these are not accidental features of the American legal landscape, but rather core elements of our claim to be the world's leading democracy. I visited too many other countries with shadowy "Ministries of the Interior," that spy upon and detain citizens in the name of homeland security. Almost alone among the world's countries, I found, America treats diversity as a national asset by inviting aliens and foreign-born Americans to participate in our national community without treating them as a political underclass. Unlike many countries that have accepted the unexamined rule of individuals, we have recognized instead that officials of all three branches should conduct their acts openly, and under the rule of law.

The various laws and orders passed since September 11 threaten to stand all three of these principles on their heads. But why isn't this a moment to reaffirm these principles, not jettison them? We need not conduct overbroad detentions and withhold names, at a time when the public unanimously supports aggressive law enforcement, and judges and magistrates would grant any reasonable warrant. We should not target foreign-born citizens and lawful residents for discriminatory investigations and indefinite detentions at a time that we most need national unity and foreign support. Why try suspects before untested military commissions unauthorized by Congress at a time when our federal courts have fairly and openly tried and convicted more than two dozen al-Qaeda members without acquittals, compromise of classified information, or attacks on jurors or judges?

Since September 11, a building refrain from American allies and human rights activists has been "American exceptionalism": the notion that America's power and peril have made it increasingly reluctant to play by the world's rules. While this view is not wrong, it is certainly incomplete. Looking at the half-empty part of the glass obscures the most important respect in which $21^{\text {st }}$ century United States is really exceptional. The United States remains the only superpower capable, and at times willing, to commit real resources and to make real sacrifices to build, sustain, and drive an international system committed to international law, democracy, and the promotion of human rights. 
Since World War II, from FDR ${ }^{2}$ to George W. Bush, we have seen remarkable rhetorical consistency in the United States' commitments to these goals. As President Bush pointedly said in his 2001 State of the Union speech: "America will always stand for the non-negotiable demands of human dignity: the rule of law; limits on the power of the state; respect for women; private property; free speech; equal justice; and religious tolerance." What has been inconsistent has been the willingness of America's political leaders to act on these commitments when other imperatives emerge (e.g. the Cold War, the war against terrorism), or to support and build international human rights regimes that constrain short-term U.S. freedom, while offering longer-term benefits (e.g. the International Criminal Court).

Although other countries have sounded, and at times acted upon, human rights themes, the U.S. remains unique in its ability to move the global system, for better or ill, toward those ends. If we stress too often the ways in which the United States is now the problem, we tend to forget the many trouble spots in the world where if the United States is not the solution, there is no solution. Absent America's exceptional global leadership, as we currently see in the Mideast, and as we saw in Bosnia, Rwanda, and Kosovo, U.S. inaction and failure of leadership can pose far greater threats to human rights than its intemperate action.

As this war on terror wears on, a transcendent issue in the debate over U.S. foreign policy will be what kind of new world order is emerging, and what America's role in it will be. America's choice is not isolationism versus internationalism, but what version of internationalism we will pursue: a powerbased internationalism, in which the U.S. gets its way because of its willingness to exercise power whatever the rules, or a norm-based internationalism, in which American power derives from its fidelity to universal values of democracy, human rights, and the rule of law which America proselytized to the world. As a nation conceived in liberty and dedicated to certain inalienable rights, the United States has strong primal impulses to respond to crisis not just with power alone, but with power coupled with principle. September 11 has brought the legal system under which we were raised under tremendous stress. In the months ahead, the challenge will be for all of us, as lawyers, academics, researchers, and activists, to prod our government to follow more consistently the better angels of our national nature.

\footnotetext{
${ }^{2}$ Franklin Delano Roosevelt, $32^{\text {nd }}$ President of the United States, 1933-45.
} 